\title{
Particular Values and Critical Morality
}

\author{
Jeremy Waldron $\dagger$
}

In this paper I consider and criticize the following position: a community is entitled to uphold and enforce its own distinctive mores, norms, and standards through the agency of the law, even though this enforcement may seem undesirable from the wider point of view of hiberal morality or moral philosophy. According to this view, which is often labeled "communitarianisn1," a community is entitled to do this for the sake of its own moral and cultural particularity, and in order to preserve its unique identity, its boundaries and its heritage.

\section{I}

\section{CRITICAL Liberalism AND THE COMMUNITARIAN RESPONSE}

When someone is condemned for violating the moral norms of her conıniunity, one typical response-which I shall call the liberal response-is to subject those norms to critical evaluation, and ask whether they embody just and desirable standards for the regulation of hunian conduct.

The controversy over the Supreme Court's decision in Bowers $v$. Hardwick ${ }^{1}$ provides a good exanıple. In that case, the Court upheld a Georgia statute that prohibited sodomy and disnissed the respondent's argunient that he had a fundamental right to engage in acts of consensual sodoniy: "[T]o claim that a right to engage in such conduct is 'deeply rooted in this Nation's history or tradition . . . is, at best, facetious."2 The liberal argument for the respondent's position was that, whether such a right is fundaniental depends not on its historical roots, but on its iniportance for the fulfillnient of basic hunian needs. Honısexual intimacy can be classed alongside other intimate activities as part of the sphere of autonomy necessary for the flourishing of hunian personality. Because people need to be able to relate to one another intiniately and

$\dagger$ Professor of Law, Jurisprudence and Social Policy, Boalt Hall School of Law, University of California, Berkeley. D.Phil. 1986, Oxford; M.A. 1980, Oxford; LL.B. 1978, Otago, New Zealand; B.A. 1974, Otago, New Zealand.

1. 478 U.S. 186 (1986).

2. Id. at 194. Justice White, writing for the majority, arrived at this conclusion after examining the long history and tradition of criminal penalties for sodomy in the United States. The majority's focus on tradition and community standards as a basis for its holding might properly be called "communitarian" in the sense described in this article. 
sexually, and because not everyone finds fulfillment in the same rigid categories of gender and sex, the law ought to be as tolerant as possible in this area, at least where consenting adults.are involved and no one is suffering any harm. ${ }^{3}$

Liberals need not deny, at least for the sake of argument, that the condemnation of homosexual activity represents a moral consensus in the commumity. But they insist that a community consensus is not selfvalidating. To validate it, one must see whether it measures up to abstract principles drawn out of the very idea of individual fulfillment and the respect people owe to one another. These principles are arrived at and formulated in a way that is supposed to be applicable to any society, applicable to the interaction of any beings like ourselves. ${ }^{4}$ If the communal consensus measures up to these principles, then it is considered just. But if it does not, the liberal test condemns the norms and the community that embodies them as oppressive and inhumane.

In recent years, this approach has elicited a series of responses that have become known under the general heading of communitarianism. A number of writers have argued that the standards against which liberals measure the societal norms place too much stress on individual rights, individual fulfillment, and individual respect, and too little emphasis on the social conditions that make individuality possible, and on communal concerns taken as important in their own right. ${ }^{5}$

In addition to this, several communitarian writers have developed a more radical critique. They have argued that there is something fundamentally misconceived about measuring the moral culture of a particular community against any set of abstract standards, whether those standards ascribe importance to communal values or not. The fissure in modern social thought, they say, is not merely between individualist values and communitarian ones; it is between particularity and abstraction-the concrete reality of the norms of a given society and the abstract principles with which liberals purport to evaluate them. ${ }^{6}$

3. See id. at 204-05 (Blackmun, J., dissenting). See also Comment, History, Homosexuals and Homophobia: The Judicial Intolerance of Bowers v. Hardwick, 19 CoNN. L. Rev. 129 (1986); Sheppard, Private Passion, Public Outrage: Thoughts on Bowers v. Hardwick, 40 Rutgers L. REv. 521 (1988).

4. The locus classicus of this approach to social evaluation in modern thought is J. RAWLS, A THEORY OF JUSTICE (1971).

5. See, e.g., Taylor, Atomism, in Powers, Possessions and Freedom: Essays in Honour of C.B. MACPHERSON 39, 48-50 (A. Kontos ed. 1979); M. SANDEL, LiberalisM AND THE Limits OF JUSTICE (1982).

6. This line of communitarian argument is developed most fully in the work of Alasdair MacIntyre and Michael Walzer. See A. MacINTYRe, AFTer VIRTUE: A StUdy IN MORAL THEORY (1981) and Is Patriotism a Virtue?, The Lindley Lecture, U. Kansas (Mar. 26, 1984); M. Walzer, Spheres of Justice: A Defense of Pluralism and Equality (1983). See also R. Bellah, R. Madsen, W. Sullivan, A. Swidler \& S. Tipton, Habits of the Heart: INDIVIDUALISM AND COMMITMENT IN AMERICAN LIFE 142-63 (1985) (discussing the American 
Liberals pride themselves on being able to discern, amidst the variety of different ways in which humans live in this world, a certain number of basic needs, interests, vulnerabilities and capacities that each of us possesses-features that are common points of concern, part of our common humanity, part of what any society should address. They say, for example, that we can all feel pain, develop affection, form families, make plans, fear and suffer loss, speculate about God, discipline ourselves, hold views, jom together in clubs and associations, have fun, experience beauty, and so on. On the basis of soine such list, liberals purport to give a general account of what a society must be like if it is to accommodate the sort of beings we are. ${ }^{7}$

By contrast, communitarians, such as Alasdair MacIntyre, stress the uniqueness and distmctiveness of our situation in a particular social structure:

I am someone's son or daughter, someone else's cousin or uncle; I am a citizen of this or that city, a inember of this or that guild or profession; I belong to this clan, that tribe, this nation. ... As such, I inherit froin the past of my family, iny city, my tribe, my nation, a variety of debts, inheritances, rightful expectations and obhigations. These constitute the given of iny life, my inoral starting point. This is in part what gives my hife its own inoral particularity. 8

Liberals of course have never denied that some features of a person's moral life are distinctive in this way, depending on her particular history and on the particular life she has led. People have special rights (and duties) arising out of promises, acquisitions, roles and relationships, as well as the general ones we call human rights (and the duties correlative to those): the promises that have been inade to ine are not the ones that have been made to you, and so our moral situations differ to that extent. ${ }^{9}$ But for liberals the potential for creating this particularity is embedded in our general human nature-for example, our capacity for making particular promises is bound up with our autonomy, as an over-archimg and

myth of individualism and the limits it puts on us all when we try to establish concrete and meaningful social commitments). Its importance has also been persuasively argued by Philip Selznick, to whom I am indebted for many conversations on these issues.

7. For different approaches along these lines, see H. HART, THE CONCEPT OF LAw 189-95 (1960) (defining "minimum content of natural law"); B. W1LL1AMS, The Idea of Equality, in Problems OF THE SElf 230, 232-39 (1973) (discussion of "common humanity" and "moral capacities"); J. RAWLS, supra note 4, at 90-95, $395-99$ (primary goods). See also Waldron, Theoretical Foundations of Liberalism, 37 PHIL. Q. 127, 144-45 (1987).

8. A. MAcINTYRe, AfTer ViRTue, supra note 6, at 220.

9. For the distinction between special rights and general rights, see Hart, Are There Any Natural Rights?, in ThEORIES OF Rights 77, $84-88$ (J. Waldron ed. 1984). See also R. NozicK, ANARCHY, STATE AND UTOPIA (1974) (Nozick's theory of historical entitlement is, in effect, an application of the idea of special rights, with the particularity that goes with them, in the realm of distributive justice. This is discussed more fully in J. WALDRoN, THE RIGHT to Private PROPERTY 253-83 (1988)). 
universal human interest-whereas the suggestion in MacIntyre's account is that our natures may be, so to speak, particular and special all the way down. According to this view, there may be nothing more to be said about human nature, for the purposes of social and political evaluation, than that the nature and interests of each person are constituted by the concrete social setting in which she lives.

Michael Sandel has proposed something similar in his criticism of contemporary theories of autonomy and commitment. According to Sandel, when liberals write about the particular commitments and relationships that people may have, they suggest that each of us is capable of standing apart from the things in which we are involved. They contend that the self is to be identified as the entity that chooses them and can give them up if it wants, rather than identified in terms of the content of what it has chosen.

One consequence of this distance is to put the self beyond the reach of experience, to make it invulnerable, to fix its identity once and for all. No commitment could grip me so deeply that I could not understand myself without it. No transformation of life purposes and plans could be so unsettling as to disrupt the contours of my identity. No project could be so essential that turning away from it would call into question the person I am. ${ }^{10}$

Liberals insist that society must be made safe for a self that is autonomous in this sense: a self not enriched by any of the constitutive commitments that make someone the particular person she is. Social norms are to be evaluated for their effect on this independent self, rather than taken in themselves to be part of the essence of the persons who have grown up and nurtured their identities within the social framework that they define.

According to Sandel, the "thin-ness" of this approach is ultimately self-refuting. Liberals imagine that they are vindicating the claims of moral agency, but, to the extent that moral agency is bound up with character and refiection, they are taking away the ground that it rests on.

To imagine a person incapable of constitutive attachments ... is not to conceive an ideally free and rational agent, but to imagine a person wholly without character, without moral depth. For to have character is to know that I move in a history I neither summon nor command, which carries consequences none the less for my choices and conduct. ${ }^{11}$

In the end, Sandel argues that the only agency in the world is particular, situated agency, and the only people for us to respect in society are particular situated people. We cannot judge laws and mores in the abstract

10. M. SANDEL, supra note 5 , at 62 .

11. Id. at 179. 
by analyzing how they affect human interests considered independently of the societies that define them:

[W]e cannot regard ourselves as independent in this way without great cost to those loyalties and convictions whose moral force consists partly in the fact that living by them is inseparable from understanding ourselves as the particular persons we are-as members of this family or community or nation or people, as bearers of this history, as sons and daughters of that revolution, as citizens of this republic. Allegiances such as these are more than values I happen to have or aims I "espouse at any given time." They go beyond the obligations I voluntarily incur and the "natural duties" I owe to human beings as such. They allow that to some I owe more than justice requires or even permits, not by reason of agreements I have made but instead in virtue of those more or less enduring attachments and commitments which taken together partly define the person I am. ${ }^{12}$

Thus, communitarians of this persuasion are not content with the abstract propositions that man is a social animal, and that communal bonds have an importance equal to or greater than the values associated with individuahity. They argue also that the culture, language, traditions, and mores of each commumity make a particular claim on the allegiance of the members of that community, a claim that goes to those members' identities and cannot be comprehended purely in terms of the general functions that tradition and mores serve in the constitution of human life.

\section{II}

\section{Agent Relativity: A Framework for ANALyzing the COMMUNITARIAN RESPONSE}

I shall begin my examination of this communitarian position by employing a concept that moral philosophers have used to categorize different types of moral principles. This is the concept of agent-relativity.

A principle is agent relative if it assigns different goals or aims to different agents; a principle is agent neutral if it assigns exactly the same goal to different agents. ${ }^{13}$ A simple example of agent-relativity is the principle of parental concern-the idea that parents should bear a special concern for their own children. The general principle is similar for all parents, but the specific object is different for each set. This couple is to be concerned with this child, that couple with that child, and so on. So parental concern is to be distinguished from another principle with which it co-exists: namely the more diffuse principle that requires us all

12. Id.

13. See D. PARfit, Reasons and Persons 55 (1984); see also Sen, Rights and Agency, in Consequentralism AND ITS CRITICS 187 (S. Scheffler ed. 1988). 
to be concerned for the well-being of children generally. This latter principle requires each of us to be concerned about the welfare of every child. As such, it is agent neutral, because it gives each agent exactly the same object.

Egoism provides another example of an agent-relative theory. Although it can be universalized as a theory for everyone ("Everyone ought to pursue her own self-interest"), it nevertheless gives each agent a substantively different goal ( $X$ 's goal is $X$ 's interest, $Y$ 's goal is $Y$ 's interest, and so on). $\dot{\text { It }}$ is therefore distinct from the particularist egoism of the megalomaniac ("Everyone ought to pursue my interest"), and from altruistic utilitarianisn ("Everyone ought to pursue the interests of all"), both of which are agent neutral.

It is important to recognize that not all agent-relative principles are the same. There is an interesting distinction between those that are normative from the point of view of others and those that are not. For exaniple, although the principle of parental concern instructs each parent to look out for her own child rather than the children of others, it still makes perfect sense for one set of parents to be concerned about and to condemn another's dereliction of this duty. By contrast, a principle such as egoisın-though it can be formulated universally-looks odd if it is made the object of inter-personal concern. There is something incongruous about one scrupulous egoist condemning someone else for not being sufficiently egoistic. ${ }^{14}$ If egoism is a duty, it is almost as though the duty and not just the object of the duty is the special and private concern of each agent.

What is this distinction based on? A couple of possibilities spring to mind. First, some agent-relative principles and concerns are located against a background of niore diffuse concerns which are agent neutral. For example, the principle of parental concern is backed up by (perhaps even largely derived from) the general concern for children that I mentioned earlier. Our fundamental purpose is the welfare of all children; but we think this is best promoted if parents look after their own. This agent-neutral background then explains why one set of parents may properly be concerned about the children of other parents, and about other parent's dereliction of the (agent-relative) duty that they owe their children. By contrast, other agent-relative principles stand alone without a background of diffuse concerns. Though egoism is sonetimes defended against a utilitarian background in a sort of "invisible hand" way, ${ }^{15}$ usually it stands by itself as a fundanental position, with nothing to provide

14. See Medlin, Ultimate Principles and Ethical Egoism, 35 Australasian J. Phil. 111, 11118 (1957).

15. The most famous example is A. SMITH, AN INQUiRy iNTo the NATURE AND CAUSES of The Wealth of Nations, 456 (R. Campbell \& A. Skinner eds. 1976) ("By pursuing his own 
any foothold for one egoist to commend the egoism or condemn the selflessness of another.

Second, some agent-relative concerns are competitive whereas others are not, or not to the same degree. To the extent that individuals are locked into some sort of Hobbesian strnggle, it would be self-defeating (not just odd) for one egoist to commend egoism to another. But when one's goals do not compete with others' goals, one can coherently be morally concerned about others' following the aims assigned to thein. That is usually the case with parental concern. Except where parents are coinpeting, say, for scarce educational places for their children, their concerns are not usually inimical to one another, and so one parent's cominendation of parental sohcitude to another makes a lot more sense.

When agent-relative concerns are competitive (and sometimes even when they are not), there is a certain incongruity about the agent's characterizing her concern in umversalized terms. When asked what she is doing, the egoist is unlikely to say, "I am following the universal principle that requires everyone to pursue her own self-interest," for this seems too inuch like an outsider's description of what she is doing, rather than a description that captures it for her. The same may even be true of parental concern. There is something cold and heartless about a parent saying, of her concern for her child, that she is following the universal primciple that requires each parent to look after her own children. A better way of capturing how it feels for her would be to say that she is simply attending to Sally's needs or whatever. It seems characteristic of inany agent-relative concerns that when they are formulated in terms appropriate to a universalized primciple, they lose something of the flavor of the agent's internal point of view. This, as we shall see, is quite iniportant.

I want to use this philosophical apparatus to examme the view that I mentioned at the beginning of the paper, about the particularity of communal bonds and communal nores. It is fairly clear that that view has a strong scent of agent-relativity about it (if we regard each community, for the time benig, as an agent). By contrast with the agent-neutrahity of liberalisn, communal particularity assigns different aims to different conımunities. This community is rightly and properly concerned with its own distinctive moral heritage; that community with a moral heritage of its own that may differ from the first; and so on.

The question I want to explore, and on which my critique of this aspect of conimumitarianism will be based, is whether this is the kind of agent-relative concern that is capable of being normative froin an

interest [the individual] frequently promotes that of the society more effectually than when he really intends to promote it."). 
outsider's point of view. I suspect that it is not, and I want to take that as a basis for suggesting that it is odd to say, from inside a community, that these are our norms and that is the reason why we are enforcing them. Just as the parent's point of view is better captured by saying, "This is Sally and that's why I'm concerned," than by saying, "I am a parent, and this is my child," so the internal point of view of a community is better captured by saymg, "This is sodomy (or whatever) and that is why it is wrong," and by taking that seriously, than by saying, "This is the norm that happens to be distinctive of our community." Moreover, if, in a culture like ours, taking a norm seriously means trying as hard as we can to see whether or not it is really right, then the communitarian attack on liberal evaluation starts to seem more like a betrayal of our heritage than a celebration of its particularity. That is what I shall argue.

III

Agent-Relativity and Communal Particularity: THREE EXAMPLES

I want to illustrate these points with three examples of values and concerns associated with communal particularity: (1) the survival of a particular language; (2) the particularity of patriotic obligations; and (3) the authority and enforcement of a particular set of communal norms or mores. Obviously, the third of these will be the main focus of our interest.

\section{A. Language}

Consider first the issue of the survival of a language that is on the point of dying out. Welsh will do as an example: it is a language struggling to maintain its position in Wales against the overwhelming competition of English, the language of authority and convenience in the United Kingdom at large.

It is obvious that every community-Wales as much as any otherneeds a language, and preferably one that is rich enough to express the variety and depth of the ideas that are involved in a nodern society and in its science, ethics, economy, culture, literature and history. That much can be stated at the level of an abstract proposition. But the need, understood in this way, could be filled by any language which satisfied those conditions and which was fully understood by the menibers of the society. English could certainly serve that purpose in Wales, except for the handful of native speakers of Welsh who are not fully bilingual. Indeed it would probably serve better. It is a richer language with a much larger vocabulary and expressive power. It makes available a literature orders of magnitude greater than that available in Welsh, it enables the people of Wales to interact freely and fully with their fellow citizens 
in the United Kingdom, and it offers them a much better prospect of being understood abroad.

So the case for preserving the Welsh language cannot be stated in terms of the abstract need which every community has for a language. It has to be stated in terms which refer to the fact that this language is special to this commumity, that it is part of the historic and cultural identity that the members of the community share and that makes them what they are. Understood in this way, it is not something which is "fungible", that is, fully replaceable by any functional equivalent, by any other language that would facilitate communication and social interaction as well.

Now notice some points about this example. First consider what I referred to as the "abstract need" that each society has for a language. In fact there is no simple opposition between "abstract" and "particular" here. Though it is true, as a umversal proposition, that every society needs $a$ language that will satisfy functions $A, B$, and $C$, of course what is the case is that every society needs some language in particular and not merely the abstract idea of a language. So the special point about particularity in the case of the preservation of Welsh has got to be inore than that: it has got to be, not only that Wales needs some language in particular, but that it needs this language in particular and that no other particular language will do even if it satisfies functions $A, B$, and $C$.

Secondly, though we have contrasted the abstract need for a language with the particular relation of Welsh to Wales, the clain that we are making about the latter relation is nevertheless one that can be stated in abstract and universatized terms. After all, our point is not only about the importance of Welsh to Wales; it suggests also that Gaelic may have exactly the same sort of particular importance to the people of the Scottish Highlands, that French has a similar importance for Quebecois society and so on. Though the relation of a particular language to a particular people is special, irreducible and nonfungible, it may nevertheless be a type of relation that other languages have to other peoples. Indeed something like this has to be the case, or else the particular clain that the Welsh were making would be quite unintelligible to outsiders. We can state this importance in a general way, in the words of Herder: "Has a nation anything more precious than the language of its fathers? In it dwell its entire world of tradition, history, religion and principles of existence; its whole heart and soul." 16 Though his point is about $a$ nation (in the sense of any nation), it is about the intimate one-on-one relation of each particular nation to its own particular heritage.

16. Cited in A. SMIth, The Ethic Revival 166 (1981). I am grateful to Glyn Morgan for this reference. 
Thirdly, we must distinguish this claim about the specialness of a particular language to a particular community frons a claim about the general importance of sustaming linguistic variety in the world and of preserving as many living specimens of language as we can. The latter is an outsider's claim: It is the claim, for example, of a hinguistic scholar who regrets the demise of Latin even though she has never been to Ronie, or sheds tears over the disappearance of Cornish despite the fact that she has no roots in Cornwall leerself. It is a claim coniparable to that of the ecologist who is concerned about the preservation of species as such, and who tells us every year how many different types of moth have died out, or how many fewer species of birds there are, due to hunianity's depredation of the environment. Behind both clainis-the linguist's and the ecologist's-is the idea that the world is a poorer place (less colorful, less interesting, less diverse) when some type of thing dies out. And that is probably true, but it does not capture the special concern of the insider about the particularity of her own language and culture.

The Welsh speaker worried about the imminent demise of her native tongue is not necessarily concerned for linguistic diversity at large in the world, and certainly her concern would not be satisfied if all Welsh school children were taught Latin instead. She cherishes the Welsh language because it is her lieritage, not because of the richness or poverty of some taxonomic concern.

Clearly, then, the concern of a people for the survival of their own language is an "agent-relative" concern, in the sense we have defined. Though, as we have seen, the Welsh case is nuatched by a sinilar case for Gaelic and anotler similar issue in the case of the Quebecois, still the proposition that universalizes these concerns makes it clear that each community focuses as an agent on a different object. Thouglı conıniunity $X$ 's concern for language $A$ is similar to cominunity $Y$ 's concern for language $B$, it is $A$ and not $B$ (and not botli) that $X$ is concerned with, and $B$ and not $A$ (and not both) that is the focus of $Y$ 's concern.

Certainly, some of the concerns about language that we have inentioned are agent neutral. The concern that every society should have a language is a general and neutral concern, which might even be satisfied by giving each society the sanie language (Enghish or whatever). Sinilarly, the linguist's concern for the diversity of nian's hinguistic heritage is agent neutral as well. It gives the Welsh linguist the sanie ain 1 as the Enghish linguist: naniely, that as nany living speciniens of language as possible should survive. Such concerns therefore are quite radically different in kind froin the particular concern the Welsh have for their own native tongue.

It is true that a concern about one's own language is often made the basis of a clainı against outsiders. The people of Wales not only appeal to 
each other to keep Welsh alive, they appeal also to the British government to help them in that endeavour. This seems to detract from their agent-relative character; after all, the important thing about an agentrelative principle is that the goals assigned to me are not any business of yours, and vice versa. But the claim is often a negative one ("Stop messing with our culture"), rather than a claim for positive assistance. Or if it is a claim for positive assistance and facilitation, it is a claim made to the government not as an outsider but as an entity that must regard itself as in part a representative of distinctive Welsh interests. To that extent, the agent-relative character of the concern remains.

What about the distinction we drew in Part II, between agent-relative concerns that are normative from the point of view of outsiders and those that are not? Are the Welsh hikely to be concerned if the Scots do not preserve Gaelic or if the Quebecois become lazy about their French? It seems unlikely that they would, except to the extent that the concern was based on the linguist's ideal of diversity. The Welsh of course are in a position to understand something of what it feels like for other peoples clinging to their respective traditions, and so it will be easy for thein to empathize. But they are likely to say that if other peoples do not want to preserve their own heritage then that is a matter for thein.

\section{B. Patriotism}

A second example that I want to use to develop the theme of particularity is patriotism. Patriotisin is the love, devotion, and allegiance that people are supposed to bear to their own country: it is supposed to provide a moral basis for a willingness to stand up for one's country, a willingness to defend it, and in the last resort a willingness even to lay down one's life for its sake.

In a lecture given a few years ago, Alasdair MacIntyre tried to defend the thesis that patriotisin could be a moral virtue, against what he took to be the critique of liberal philosophy, that patriotism engendered an unhealthy indifference to the requirements of international justice, a chauvinistic repudiation of the universal norms of morality, and a dangerous blindness to the faults of one's own nation-the blindness connoted in the hackneyed phrase, "My country, right or wrong."17

The difficulty arises, MacIntyre argued, from the fact that the true patriot does not bear allegiance to her country because of something independently attractive about the norms and ideals that it stands for: the American patriot does not stand by the Uinited States just because of its commitment to constitutional democracy, nor does the French patriot stand by her country because of its commitment to civilization. If those

17. MacIntyre, Is Patriotism a Virtue?, supra note 6. 
ideals were the sole basis of allegiance, their partisans would be willing to support them wherever they were found and to abandon any particular allegiance whenever those ideals were being disserved. Instead, the true patriot stands by her country first and foremost because it is her country, and it is only in the light of this prior and particular allegiance that she sees any virtues (or for that matter any vices) that it has. The virtues of her motherland are for her matters of particular pride, and its vices-if they can be recognized as such-are a matter for guilt and shame rather than an occasion for exercising the easy mobility of the liberal conscience. ${ }^{18}$

As MacIntyre put it, "The particularity of the relationship [between patriot and country] is essential and ineliminable." 19 The virtue of a person standing up for this country rather than that is determined by what the liberal would regard as the arbitrary accident of her birth:

[P]atriotism requires me to exhibit peculiar devotion to my nation and you to yours. It requires me to regard such contingent social facts as where I was born and what government ruled over that place at that time, who my parents were, who my great-great-grandparents were and so on, as deciding for me the question of what virtuous action is-at least insofar as it is the virtue of patriotism which is in question. ${ }^{20}$

Clearly, patriotism has the feature of agent-relativity that we talked about earlier. Though we may state it as a universal principle- "Each person owes patriotic devotion to her motherland"-it is a principle which generates concretely different requirements for different agents, depending, obviously, on what their motherland is. Again the clash with liberal morality is the clash between an agent-relative and an agent-neutral theory: each patriot is necessarily a partisan of her own country's claims, whereas the liberal ideal requires of each of us loyalty to the same substantial principles of international morality and justice.

But the example of patriotism also illustrates the additional complication that we have noticed in the idea of agent-relative concern: how should we view one patriot's attitude toward the patriotism or lack of patriotism of another?

If we speak of a universal (albeit agent-relative) principle of patriotism, we seem to have it in mind that the Germans can recognize, respect, and even encourage in the French the latter's devotion to France, just as the French can recognize, respect, and encourage the Germans' devotion to their nation. On this rather chivalric model, French soldiers may even criticize Germans who fail to stand against France when the two coun-
18. Id. at $3-4$.
19. Id. at 5 .
20. Id. 
tries are at war (in roughly the spirit im which one parent may criticize another for failing to look after her children).

But though that model has its attractions-mutual respect among enemies, for example-it can sometimes seem a little contrived and artificial. A psychologically more realistic model may have the French soldiers feeling the normative force of patriotism so far as their own allegiance to France is concerned, but feeling no disposition whatever to commend or encourage an analogous allegiance on the part of a foreigner, or to condemn unpatriotic foreigners when they fail to take their place in the opposite trenclies. On this more chauvinistic model, it is as though the virtue, the duty, or the very normativeness of patriotism is made agent relative, not merely its object.

On the chivalric model, we all recognize, for ourselves and our enemies, the force of the norm of devotion to one's own country, and we go our separate ways only as each of us finds out what that country is. But on the chauvinistic model, each of us feels the normativeness of patriotism as essentially bound up with what is in fact its proper object for us. Patriotism turns out to be a different phenomenon for the Germans than it is for the French: for the former it is devotion-to-Germany, rather than devotion-to-one's-country (which just happens to be Germany), and for the latter it is devotion-to-France. I do not mean that a neutral observer would fail to see the similarity; I mean that in a sense you have to be neutral or to take the stance of an outsider to grasp the analogy. From the internal point of view, the Germans would in some sense not have grasped the particularity of patriotism as it applied to them if they thought of it simply as the analogue for their own case of what the French owe to France.

What then is different between the patriotism case and the case of parental devotion? For the latter case, we can make perfect sense of one parent commendmg another's devotion to her children, or criticizimg another parent who fails to look after her brood. As I suggested earlier, part of the answer must lie in the fact that patriotism normally operates in the context of international competition (or, of course, even war) whereas parenthood does not. It is part of the point of patriotism to stand up for one's country against other countries, whereas it is not part of the poimt of the agent-relativity of parenthood that one stand up for one's children against others. ${ }^{21}$ That competitive context (not to mention the fact that true patriots are supposed to be slaughtering their putative analogues on the other side) gives the chauvinistic model more force. It explains why patriotism might be inculcated in a way that made its normativity seem special for the inhabitants of each country, rather than

21. Cf. N. MACCoRmick, Nation and Nationalism, in LEgal Right AND SociaL DEMOCRACY 247, 253-54 (1982). 
in a way that presented their allegiance as simply a counterpart of the allegiance of their enemies.

\section{Community Standards}

Different communities require different things of their members in the way of civility, decency, and morality. One community may permit polygamy, another may require monogamy. One may have a practice of strictly excludimg fathers from assisting at the birth of their children, while another may encourage their participation and frown if they are absent. One society may condemn homosexuality as wicked and depraved, while another may be much more open to it as a valid type of human relationship. Together such norms will constitute the practices and the way of life that make each community the distinctive social entity that it is.

From time to time, a moral rule in a given community may be called into question. Some members may ask whether this is a good rule to have, or they may disagree about the exact way in which it should be enforced. For example, to the extent that there is a moral rule against homosexual intercourse in parts of the United States, those whose behavior it condemns and whose lives it makes unbearable may complain that it is unjust and inhumane. Even if they are unsuccessful in that, they may raise further questions about the mode of its enforcement, asking whether it is appropriate for such a norm to be embodied in law, for example, or permitted as a legitimate basis for discrimination in housing and employment.

When questions like these are raised, one possible response (which communitarian legal theorists seem to find increasingly attractive, at least in the abstract) is to say, "Of course this norm should be upheld, for it is part of what makes us the particular community we are." If the person questioning the norm is so impertinent as to plead for tolerance, the communitarian retort is blunt:

Only a thoroughly demoralized community can tolerate everything. ... . A community without boundaries is without shape or identity; if pursued with single-minded determination, tolerance is incompatible with the very possibility of a community. For this reason tolerance as an ideal is incomplete. If community life is to survive, on either the local or national level, tolerance must at some point or another come to an end. ${ }^{22}$

On this approach, abandoning a communal norm, merely because it offends some abstract liberal principle of autonomy or respect, is like cutting off a part of our identity. We should not be persuaded to forsake

22. Post, The Social Foundations of Defamation Law: Reputation and the Constitution, 74 Calif. L. Rev. 691, 736 (1986). I am grateful to Susan Sterett for drawing this passage to my attention. 
our communal lieritage on the basis of liberal theories of morality and justice that stand apart from the particularity and distimctiveness of our communal way of life. ${ }^{23}$

This sort of response is my third illustration of communal particularity. Like the cases of linguistic leritage and patriotic devotion, the present approach seems to celebrate something as valuable and important for us (for our commumity in particular) rather than as something valuable and important for all communities across the board. The importance it accords to a given set of mores and to the way tliey constitute our communal identity is once more agent relative, relative that is to the identity of the members of this particular commumity rather than to the abstract idea of commumity as sucli. We do not expect that every society will enforce and uplold our norms; we know that the rules of other societies are different. But we clierish and support our own because they make us who we are.

As witl the other examples, it seems possible at first siglit to universalize this agent-relativity. Instead of saying simply, "These norms make us who we are," we can say, "The distimctive norms of any community make it what it is," and we ought to be able to understand any society wanting to protect itself im this way.

But the point I niade earlier about patriotism ${ }^{24}$ applies even more clearly here. An outsider sucli as an anthropologist may be able to enibrace the universalized proposition, but it may be very difficult for it to be enıbraced within the meinbership of a given conınunity (call it "community $A$ "). Certainly it seems unlikely that the umiversal proposition could have any normative force inside conimunity $A$, allowing the members of $A$ to commend and encourage people in community $B$ for reniaining faithful to the (different and contrary) mores of $B$, or to criticize them for deviations from the mores of $B$. In as mucl as a given set of moral rules constitutes the distinctive cliaracter of community $A$, it is presuniably part of that communal identity to take those rules as seriously as possible, and not to entertain then simply as "something we happen to do around liere."

Thus, suppose community $A$ condemns lioniosexuality as wicked and depraved whereas community $B$ does not. The menibers of $A$ may know this about $B$, but the very norms that make them who they are will lead thein either to condemn or, at the very least, to be bewildered and beniused by the contrary attitudes of that other society. They will not view $B$ 's fidehity to its different norms as one parent views the discharge of parental duties by another. They will not say to themselves, "Ol1

23. The locus classicus of the this approach in recent legal philosophy is P. DevLin, The ENFORCEMENT OF MORALS (1965).

24. See supra text accompanying notes 17-21. 
good, community $B$ is remaining faithful to its identity as we are to ours." As with my chauvinistic model of patriotism, the whole normative apparatus of approval and condemnation will be bound up with the contents of each moral code. Whereas in the parenting case it is merely the objects of the normative attitudes that are agent relative, here it is the normative attitudes themselves.

The point needs to be qualified a little, but only in a way that makes its force even clearer. In a given community there may be some norms that are understood by its members as nothing much more than "the way we happen to do things around here." The norms for beginning and ending letters may be an example: the fact that we begin with "Dear John" rather than "John:" and sign off with "Yours sincerely" rather than "Good-bye for now." Other societies do these things in different styles and it is not a difference we take particularly seriously (indeed, it is part of our identity that we do not take such things especially seriously). The norms of letter writing serve their purpose even though those whose behavior they govern have thoroughly internalized the point that they are simply matters of convention. So we are in a position to think it perfectly appropriate for members of some other community to end their letters with exclamations like "Allah be praised!" or conventional optatives like "May your loins be fruitful!" even though we would never do the same.

But norms we treat like that are to be contrasted with others we do not treat in this way. Though we recognize that other societies have attitudes toward race, for example, that are different from ours, we do not in any sense endorse their practice of their norms on that matter, nor do we think their racism "appropriate for them." The very considerations that make us condemn racism around here also commit us to its condeinnation in other societies.

Partly this is a matter of how seriously we take the norm of ours that is in question. Partly it is also a matter of how that norm is understood. A community like the United States cannot found itself upon something it takes to be a "self-evident" truth-"that all people are created equal"- and then go on to say glibly, "But that's just what we happen to think around here; different attitudes toward equality are distinctive of and valid for different societies." A person who says anything like that from within our society betrays our norms (and hence our communal identity) in at least two ways. She does not keep faith with the content of our norm-namely, that it is all people (not simply all people who happen to live around here) who are said to have been created equal. Though the norm is our norm and distinctive of our community, it implicitly condemns racisin in South Africa and China, and caste systems in England and India. Anyone who fails to grasp that doesn't 
understand our norm: she doesn't understand the significance of the word "all" or, for that matter, the implied reference to a Creator.

Moreover, the attitude that is tolerant of the differing practices of other communities on this point misses our sense that human equality is utterly basic to moral behavior. The distinctive thought of our commumity is predicated on the idea that one cannot go anywhere in serious moral thought except on the basis of some assumption about the fundamental equahty of human worth. ${ }^{25}$ We are aware that some other societies do not agree with this, but we cannot simply say, "That's appropriate for thein" without appearing halfhearted about the status or episteinology of our own shared commitments.

The same is true of many distinctive norms. For example, take the "norm" rehed on by the majority in Bowers v. Hardwick: If there is a consensus condemning hoinosexuality in the United States, it is predicated upon sone thought about what is "natural" and "unnatural" in human relations and the use of one's body. One simply cannot have those thoughts and still beheve that homosexuality becomes perfectly appropriate for a society whose norms permit it or that the ambit of our condemnation is limited by the boundaries of those who share the views of human nature that we have.

In my earher discussion of patriotism, I suggested that what fueled the chauvinistic (as opposed to the chivalric) model was that patriotisn1 was an inherently competitive virtue. ${ }^{26} \mathrm{I}$ think soinething analogous goes on im the case of communal mores. As we develop our norms and practices, we do not say snnply to one another, "Do this" and "Don't do that." We say things like, "This is the best way to hive a huinan life" and "That is unnatural." In so doing, we make claims that leave no room for any other position. It is as though there were a coinpetition to find out the best way of hining life in which the mores of various communities were rivals and conipetitors. Each community puts forward a set of answers, and none can recognize even the local validity of the others' clainns without detracting froin the force and the confidence of its own.

Interestingly, these considerations distinguish both patriotism and communal morals froin the language case. Though each society cherishes its own language, the claims that are made for any one language are not usually coinpetitive with those made by any other. The French do not maintain that "chien" is a better word for dogs than the German "hund". It is recognized on all sides that languages are sinply conventional and that recognition does not at all subvert or undermine the quality of anyone's particular affection for the language of her people. But in

25. 'Worth' in the sense discussed by Vlastos, Justice and Equality, in THEORIES OF RIGHTS, supra note 9, at 49-60.

26. See supra text accompanying notes $17-21$. 
morality, conventionalism does have that subversive implication for most of our serious positions. Our communal mores are claims we make about what is really right and really wrong on sex, justice, equality, and so forth, and their nature is to leave no room for the thought that they are merely conventional, and that contrary claims may be also right for those who make them.

None of this shows that our local moralities are "correct" in making the grandiose and universal claims that they do. But that they make such claims is beyond dispute. It is simply not possible to understand (for example) Clristian ethics, Kantian etlics, or the morality of human rights, unless one sees that they are presented as statements of what is good and right for people everywhere. ${ }^{27}$ Moreover, the communitarian is not in a position to criticize these ethics for their universalism or imperialism. If these ethics characterize our community then, according to the communitarian, there is no point of view from which we can criticize either their content or their pretensions. Particularity-including the particularity of our moral imperialism-is all there is.

\section{IV}

\section{SHOWING Versus Saying That ONe Is FOLLOWING A NORM}

The conclusion for which $I$ have argued so far may seem to be exactly the one that the communitarian wants to reach. If the members of a given community are too immersed in their own practices to endorse or approve the differing practices of other communities, then it looks as thougl the cosmopolitanism of liberal morality is simply doomed, to say nothing of its fabled principles of toleration and moral neutrality. There is no getting outside our most cherished moral positions, no "Archimedean point" from which they may be evaluated $a b$ extra and approved, reformed, or discarded. ${ }^{28}$ There is only our community, its mores, and we, the people whom they constitute.

We have to be careful, however, low we interpret this conclusion. Communitarians seem to think it appropriate within our society to say of some widely accepted norm, "This is one of the norms that gives our community its distinctive character, and that is why it is appropriate for us to enforce it." But to describe a norm in this spirit is already to take an attitude towards it that is somewhat different from that of a person who actually subscribes to it. To subscribe to a norm like "Sodomy is wicked," is to be convinced of the wickedness of sodomy. To subscribe to a norm like "Racism is wrong," is to sincerely and wholeheartedly

27. I have developed these points a little further in "NONSENSE UPON STILTS": BENTHAM, BuRke AND MARX ON THE RJghtS OF MAN 169 (J. Waldron ed. 1988).

28. For the idea of an "Archimedean point", see J. RAWLS, supra note 4, at 260-63. 
condeinn racisin. By contrast, describing the norm in terms of the contribution it makes to our coinmunal identity means abandoning that essentially morahstic stance, and taking up a standpoint that is more external, more like the standpoint of an anthropologist who wants to know what distinguishes one community from another. It is to describe what we are doing im enforcing our norms in a way that brings out what it has in common with what a different commumity is doing in enforcing its norms. And that already mvolves a substantial abstraction from the reality of what our most serious moral commitments seem like to us.

The point can be elaborated im relation to a couple of arguments in recent political philosophy. In his book Spheres of Justice, Michael Walzer has argued that justice is a matter, for each society, of its being true to the social meanings that shape its imstitutions, its practices and its understanding of the world:

Tliere are an infinite nuinber of possible lives, sliaped by an infinite nuniber of possible cultures, religions, political arrangements, geograplical conditions, and so on. A given society is just if its substantive life is lived in a certain way-tliat is, in a way faitliful to the sliared understandings of the nienibers. . . . We are (all of us) culture-producing creatures; we make and inhabit meaningful worlds. Since there is no way to rank and order these worlds with regard to tlieir understanding of social goods, we do justice to actual men and women by respecting their particular creations. . . . Justice is rooted in the distinct understandings of places, honors, jobs, things of all sorts, that constitute a shared way of life. To override those understandings is (always) to act unjustly. ${ }^{29}$

Now if something like this is true, it does not mean that we must go around saying to one anotlier in society, "This is wliat this good or that practice means im our community, and so this is what justice inust be based on." To say that is to describe from the outside, rather tlian participate in, tlie social understandings in question. In otlier words, the trutli in Walzer's position cannot preclude our making serious and categorical claims about what is just and wliat is unjust in relation to some good or practice. It is precisely in making sucli clains that we evince our subscription to the meanings that the good or practice has for us. In making tlie claim, we are living it.

Tlie same point helps us see what lias been going on in John Rawls' recent cliaracterization of his own work on justice. Whien $A$ Theory of Justice was published it appeared to be making categorical claims about what was just or unjust in tlie way of social arrangements for any society; it was not qualified by any claim such as, "Tlis is simply what we liappen to thimk around here." The categorical tone seems present from the opening lines of Rawls' book:

29. M. WALZER, supra note 6, at 313-14. 
Justice is the first virtue of social institutions, as truth is of systems of thought. A theory however elegant and economical must be rejected or revised if it is untrue; likewise laws and institutions no matter how efficient and well-arranged must be reformed or abolished if they are unjust. $^{30}$

And Rawls goes on immediately to imply that any society, under modern conditions, should stand condemned if it (for example) subordinates liberty to economic prosperity or if it sacrifices the interests of some for the sake of the greater utility of others. He seems to be arguing, in other words, about ideals that can be applied as universal standards of criticism.

In more recent reflection, Rawls seems to say that the task of a theory of justice is more modest:

What justifies a conception of justice is not its being true to an order antecedent to and given to us, but its congruence with our deeper understanding of ourselves and our aspirations, and our realization that, given our history and the traditions embedded in our public life, it is the most reasonable doctrine for us. ${ }^{31}$

This makes it sound as though a conception of justice is expected only to capture the particularity of American (or perhaps Western) thought and practice, not to make any transcendent or overarching claim.

Much of the tension between these two approaches can be resolved by distmguishing the internal from the external point of view. From an external point of view, the priority of liberty and the rejection of utilitarian sacrifices can be seen as nothing but a part of our particular history and traditions. But from the internal point of view of those of us who have this history and share these traditions, the categorical tone of $A$ Theory of Justice is entirely appropriate. To argue in that manner is precisely what it is to be faithful to our shared understandings. Paradoxically, we cannot keep this faith by saying out loud all the time that that is what we are doing.

The point is similar to one that has been made in recent discussions in metaethics. According to an emotivist, making a moral judgement is simply expressing one's emotions; a moral judgement does not have the character of a truth claim, on this account. ${ }^{32}$ But expressing one's emotions on some issue is different from saying one is expressing one's emotions on that issue. The latter describes what is going on from an external point of view, but it does not capture the content of what is being thought, felt, and said by the person doing the "emoting."

30. J. RAWLS, supra note 4 , at 3 .

31. Rawls, Kantian Constructivism in Moral Theory, 77 J. PHIL. 515, 519 (1980).

32. The clearest and most vigorous defense of emotivism is A. AYER, LANGUAGE, TruTH AND LOGIC 136-75 (1971). 
By the same token, although in condemning racism or exploitation we are expressing and participating in the shared particular culture of our community, we are not taking the existence of that culture as our reason or as a basis for our condemnation. The reason why things like racism and exploitation are wrong, we say, is the indignity they offer to the human person. Though no doubt we would think differently had we been brought up somewhere else, it is no part of what we think on these matters that they should properly be sensitive to such differences.

In the end, the point is just an application of the Wittgensteinian dictum, "What can be shown, cannot be said." 33 In upholding social Inores, we show the particularity of our culture, just as in expounding a inoral view we show the emotions that we are expressing. But the moral view that we are expressing is muddled or distorted if what we say, as we expound it, is that it is an expression of our enotions. And likewise, the particular identity of our community on moral matters is obscured or betrayed, if we say that preserving that particularity is what we are doing as we uphold our social norms.

\section{$\mathrm{V}$ \\ Is There A Communal Consensus?}

There is one last step to make in the arguinent. I have said that a cominumitarian betrays rather than participates in our communal identity by taking that particular identity as itself a ground for moral or political action. By asking what is really right and really wrong, the liberal is closer to participating in the spirit of our traditions than the coinmunitarian who says that what matters to us is nothing more than that these happen to be our traditions.

So far I have left unexamined the question of the homogeneity of these mores that are said to be ours. If there are widely shared values and understandings in our culture, then we can respect that consensus (if that is what we want to do) only by subscribing to them and immersing ourselves in tlem, and not by stepping outside them and talking about their particularity. But is there such a consensus? What is this community and who is this "we" we keep talking about? Answers to these questions quickly indicate that the liberal approach is even closer than the coinınunitarian to the spirit of such shared understandings as we have.

\section{A. The Problem of Defining "Community"}

When we speak of the moral norms of a community, it is tempting to think of a relatively simple moral consensus, one that forms a

33. L. Wittgenstein, Tractatus Logico-Philosophicus 51 (1961) (prop. 4.1212, emphasis in original). 
homogenous, enduring, uncontroversial, and relatively unreflective basis for our lives, culture, and traditions. But there can be no doubt that such an image is unrealistic, at least for a community in the modern world. There is nothing that we can call the morality of a modern community that does not exhibit features like change, diversity, controversy, and self-consciousness. Any theory built on the particularity of our traditions or those of any other existing society must take account of that.

To the extent that they yearn for a body of mores that is more stable and homogenous than this, communitarians are simply indulging in fantasy or nostalgia, and they are certainly not keeping faith with the way of life that we happen to share around here. The wishful thinking of modern communitarianism is something that a number of critics have noticed:

Words like fraternity, belonging and community are so soaked with nostalgia and utopianism that they are nearly useless as guides to the real possibilities of solidarity in modern society. Modern life has changed the possibilities of civic solidarity, and our language stumbles behind like an overburdened porter with a mountain of old cases. . . Our task is to find a language for our need for belonging which is not just a way of expressing nostalgia, fear and estrangement from modernity. Our political images of civic belonging remain haunted by the classical polis, by Athens, Rome and Florence. Is there a language of belonging adequate to Los Angeles? ${ }^{34}$

One example of this difficulty is found in the way communitarians characteristically avoid or evade the definition of "community." What sort of entity is it that is supposed to have made us who we are, given us our character, endowed our lives with their particularity?

As we write these papers on the role played by "community" in our moral reasoning about the law, are we talking about some neighborhood association in Berkeley, or about the People and State of California, or about the United States as a whole? Or are our perspectives even wider than that? Are we talking about the common culture and civilization that makes it possible for a New Zealander trained at Oxford to write for the California Law Review?

We do not have to wait for an answer in order to recognize the following point: any plausible sense of community is going to refer to a hife lived together by a number of people that is large enough to render it vanishingly improbable that they all hold the same moral views on any topic you care to mention. One does not have to embrace methodological individualism to see that any community worth our interest will comprise men and women of different ages, characters, experiences, genders,

34. M. IgNatiefF, The NeEdS OF Strangers 138-39 (1984). 
moral and intellectual powers. These differences are bound to color their view of how they ought to live.

The point is obvious enough when applied to America, or indeed to any of the States that compose it: there are literally thousands of moralities jostling and competing with one another in the marketplace of American ideas, and none of them can, without distortion or special pleading, be taken as "the" particular morality of this country or the way "we" do things around here. ${ }^{35}$ One might want to argue that the morality of "our" community is what all these diverse positions have in common. But that is ludicrous: the common denominator (if one can be found) is likely to be held by nobody as a set of principles in its own right, particularly once one recognizes that people take their moralities whole, so to speak, and that any principle or value is colored by the others witl whicl it is conjoined.

The same is true of any attempt to identify "our" morality with the morality embodied in our laws, our constitution and the other formal aspects of our political life. It is notorious that these are subject to widely differing interpretations, and that those interpretations stem at least in part from the fact that people combine their constitutional understandings with other commitments they liave (their religious and ideological beliefs, for example) which cannot be accommodated in any account of the consensus that makes "us" who "we" are. ${ }^{36}$

Even if from a distance the members of a community seem to share some moral ortlodoxy, on close examination one will certainly find differences of emphasis, mterpretation, and understanding. This is not to say there is no sucl thing as a communal morality; it is to say only that any identification of a communal morahity that precludes diversity and disagreement is simplistic and sociologically naive.

One could, I suppose, simply define "community" in a way that excluded diversity of moral view. On that definition, two people could not be said to belong to a single commumity if they lield different moral perspectives. But such a definitional approach would be hopeless for social and political theory. For one thing, it would cut the term loose from any reference to a sociologically recognizable entity. Indeed it would effectively eliminate communitarian ideas as wortlyy of consideration in their own right. If a community just is all the people who loold a certain view, then appealing to the norms of the community is no different from simply referring to the norms themselves (and saying that

35. For example, even within Georgia there was not a consensus regarding the morality of homosexuality or whether it was proper to enforce the moral view against sodomy through the agency of law. See Bowers v. Hardwick, 478 U.S. 186, $219-20$ (1986) (Stevens, J., dissenting).

36. This point is well-argued in M. Tushnet, RED, WhIte, AND Blue: A CRITICAL ANALYSIS OF CONSTITUTIONAL LAW 134-46 (1988). 
several people hold them). Saying that they are embodied in a community would be adding nothing to that.

It is sometimes thought that the Aristotelian tradition in political philosophy embraced an image of community that was united by a common view of ethics, that the polis comprised a group of people who shared the same norms and traditions, and that this was incompatible with the sort of diversity to which I have referred. In fact, as an interpretation of Aristotle, nothing could be further from the truth. When Aristotle wrote, in a famous passage, that "Nature . . . does nothing without some purpose; and for the purpose of making man a political animal she has endowed him alone among the animals with the power of reasoned speech,"37 he did not mean that our power of speech was our ability to chant moral slogans in unison. On the contrary, he recognized that we can hope as a community to attain knowledge of goodness and justice only by conversation among people who bring different views, perspectives and experiences to political life. If we accept the Aristotelian claim that no one individual can arrive at the truth about goodness on her own, it follows that apprehension of goodness can never be a matter of simple unanimity either. ${ }^{38}$ In this respect Aristotle's views (and those of other thinkers in his tradition such as Aquinas) are closer to those of someone like John Stuart Mill than to those of the modern communitarians who condemn pluralism and yearn for moral homogeneity. ${ }^{39}$

These points are confirmed when we consider that, whatever a community is, it is something that endures through and therefore changes over time. A community has a life that is longer than any of its members, but longer too than that of any of the circumstances and problems to which its particular mores are a response. We cannot predict how the norms and shared meanings of a community change with changing circumstances (indeed it is arguably a condition of communal particularity that this is unpredictable), but change there will certainly be in any community worth taking seriously in the modern world.

It follows immediately that it is impossible and wrongheaded to talk about the morality of a community, if what is meant by "morality" is a

37. Aristotle, The Politics, Bk. I, Ch. 2, at 28 (T. Sinclair trans. 1962).

38. Id., Bk. II, Ch. 4-5, at 60-68 (criticizing the "excessive unity" of Plato's imagined republic); Bk. III, Ch. 4, at 108 ("a city is made up of unlike parts"); and Bk. III, Ch. 11, at 123-4 (arguing that a mass of individuals, each with different abilities, may make better decisions together than any one of them is capable of alone).

39. J. Mill, ON LiBerTY 58 (C. Shields ed. 1956) ("Truth, in the great practical concerns of life, is so much a question of reconciling and combining of opposites that very few have minds sufficiently capacious and impartial to make the adjustment with an approach to correctness, and it has to be made by the rough process of a struggle between combatants fighting under hostile banners."). See also T. AQuinas, On Princely Government, in Aquinas: SElected Polrtical WRITINGS 1, 3 (A. D'Entreves ed. 1959) (no one man can attain all necessary knowledge of wellbeing for himself, and so some division of labor is desirable). 
settled consensus on an identifiable set of first-level standards of conduct. As circumstances change, moral standards will be in flux, new ones overlapping with old ones, sometimes challenging them, sometimes shoring them up, and, of course, some held by some members or generations in the community and some by others. At best, talk of a community's morality can only be a reference to the particular features of the flux itself and the different ways in which people cope with change; there is no sense at all in setting up an antithesis between communal morahty, on the one hand, and changing standards on the other.

Again, it may be possible to define a sense of "community" so that it simply means a set of people who maintain exactly the same moral views. But if we take this approach then, whenever moral change takes place, we have to say that one community has been replaced with another. ${ }^{40}$ Once again the definitional move is sterile. It leaves us with no argument at all for preserving one community (so defined) rather than another, especially once we recoguize that moral change and controversy over time is a natural part of the life cycle of whatever it is that endures when successive generations of men and women make a life for themselves together.

\section{B. Critical Morality as a Community Norm}

It is an important feature of the morality or moralities of our modern society that there is a lot of self-consciousness about all this. Not only do different moral outlooks coexist and succeed one another, but it is distinctive of our society that we recognize this and that we evolve and develop various second-level standards and practices for coping with it (standards and practices which are themselves self-conscious, controversial and in flux). For exaniple, even the most homogenous religious group in America will be aware that it coexists with others, and that many of those others combine their religious faith with a commitment to such things as mutual toleration, the separation of church and state, and a self-denying refusal to embody specifically religious standards in positive law.

H.L.A. Hart once argued that the question of the enforcement of moral standards is a question in critical morality about the enforcement of the particular positive or conventional morality of the group. ${ }^{41}$ But that need not be so: the question of enforcement is likely to be an issue

40. This is the move that H.L.A. Hart accused Patrick Devlin of making in his argument for the enforcement of morals. See P. DEVLIN, supra note 24, at 9 ("Every society has a moral structure. .."); and H. HART, LAw, LIBERTY AND MORALITY 52 (1963) ("[I]t is only on this absurd criterion of what it is for the same society to continue to exist that it could be asserted without evidence that any deviation from a society's shared morality threatens its existence.").

41. H. HART, supra note 40 , at 20 . 
addressed at the level of positive morality as well. For whatever our modern mores are, they are anything but unsophisticated: they are complex, they are articulate, and they deal with issues at a number of different levels. So one does not have to embark on an allegedly liberal repudiation of our traditions and take off into abstraction in order to raise questions about whether this or that local standard should be enforced. It is part of our particular heritage to address moral questions in this reflective mode.

In general we need to remember that men and women in a commumity are not the unthinking bearers of timeless convictions that commumitarians make them out to be. Even when they are fully immersed in the practices of their commumity and imtoxicated with its ethics, men and women see how the world goes and feel its pains and pleasures. They are creatures of experience, memory, thought, and above all imagination, and they are capable of entertaining and sharing with one another, in outrage or in hope, the possibihty that things imght go differently and indeed better than they are currently gomg in the circumstances they face.

To do that, they have to be capable of thinking that their social world might be different from what it currently is, and that they themselves (to the extent they are socially defined) imight be different froin the way they currently are. They have to be capable of saying, "Things would be better for us, or people hike us, if different practices were adopted," and they have to be capable of acting on that thought. The modern fashion among commumitarians is to condemn such imagination as mauthentic, to say with Sandel that it leaves the self that is entertaining these thoughts with no essential social attributes, no social attributes that are beyond challenge from such imagination. ${ }^{42}$ But whether commumtarians like it or not, such a capacity is undoubtedly part of our particular heritage. And I think that, in their shoes, I should start to question my use of ill-understood terms like "constitutive" and "essential" in this context, before I dreamed of denigrating it. ${ }^{43}$

In many societies, the epitome of this reflective capacity is the development of traditions and practices of specialist reflection on local mores, ranging from rabbimical casuistry through the institutional practice of moral and pohitical philosophy in the modern university. ${ }^{44}$ These are our practices of "critical" morality, involving sustained, conscientious and

42. M. SANDEL, supra note 5, at 54-65; see also supra text accompanying note 10.

43. See Waldron, When Justice Replaces Affection: The Need for Rights, 11 HARV J. L. \& PUB. POL'Y 625, 646 (1988).

44. Cf. Laslett, Introduction, in Philosophy, Politics AND Society vii (P. Laslett ed. 1956) ("It is one of the assumptions of intellectual life in our country that there should be amongst us men whom we think of as political philosophers."). 
rational thought about moral ideas and social possibilities. They are part of what the commumitarians have in mind when they attack those who apply "abstract" and "liberal" criteria to the evaluation of communal standards.

The charge of abstraction has at least two counts to it. In the first place, the worry is that "critical" moral thought is simply too distant from and too little immersed in the distinctive mores of our local traditions. In the second place, the charge is that the practice of "critical" morality is overly individualistic-setting the rational faculties of one philosopher against the wisdom and tradition of ages. Both criticisms are misconceived.

The first, as we have seen, would work ouly if there were a clear line between a grounded moral consensus on value, conduct and virtue, on the one hand, and "critical" philosophical reflection on the other. But there is no such line. Critical reflection in one form or another is part and parcel of the moral consciousness of men and women in a modern conimunity like ours. There is indeed a contrast between those who approach morality in a "liberal" spirit and those who approach it more conservatively, but there is no reason whatever for saying that the latter take the particularity of our community more seriously than their liberal opponents. Since our communal heritage is diverse and volatile, since it embodies in itself questioning and controversy, one does not betray community values by taking the practice of critical reflection seriously. Indeed by immersing oneself in that practice a person keeps better faith with our traditions than soineone who appeals plaintively and nostalgically to an innagined past of moral unanimity.

The other claim is that critical inoral reflection is essentially individuahistic, in its style and practice if not in its content and conımitments. The image that accompanies this criticisin is that of the solitary philosopher, alienated from the society that supports her, sitting in her armchair, her garret, or her ivory tower, setting up her individual reason as rational censor of the morals of the community. The image is nicely carried in some phrases of Edmund Burke, condemning the moral mnovations that accoinpanied the French Revolution:

We are afraid to put men to live and trade each on his private stock of reason; because we suspect that this stock in each man is small, and that individuals would do better to avail themselves of the general bank and capital of nations, and of ages. . . . Your literary men, and your politicians, and so do the whole clan of the enlightened among us, essentially differ in these points. They have no respect for the wisdom of others; but they pay it off by a very full measure of confidence in their own. Witlr them it is a sufficient motive to destroy an old sclieme of things, because it is an old one. As to the new, they are in no sort of fear with regard to the duration of a building run up in haste; because duration is no object 
to those who think little or nothing has been done before their time, and who place all their hopes in discovery. ${ }^{45}$

But the Burkeian attack was a travesty when it was made, and it is a travesty now. The philosophes were not individuals trading "each on his private stock of reason" with "no respect for the wisdom of others." They were themselves part of a philosophical and political community who shared ideas, not only with others in Paris, but with thinkers in England and America as well. ${ }^{46}$ Moreover they understood themselves to be thinking and conversing as part of a tradition of republican and moral thought that stretched back to antiquity. When Marx jibed that "the parties and masses of the old French Revolution performed the task of their time in Roman costume and with Roman phrases," paying unwitting tribute to the fact that the rational standards that were being brought to bear on the institutions of the ancien regime were not the private stock of some atomized individual, but a heritage of critical thinking that has always been part of our tradition, an interwoven counterpoint to whatever we have had in the way of moral and political consensus. $^{48}$

The same is true today. When moral philosophers, liberal or otherwise, subject the institutions and practices of their community to rational scrutiny, they do so as part of an intellectual community and as heirs of a tradition of thought that builds as firmly and faithfully on the wisdom of their predecessors (who took themselves to be doing the same) as any follower of Burke. One cannot read any of the classics of modern moral and political reflection without noticing the importance that is accorded to figures like Aristotle, Christ, Augustine, Hobbes, Locke, and Kant as forerunners and landmarks. These figures are not of course venerated; our practice has rather been to proceed by imagining ourselves in a sort of dialogue with them across the ages. Moreover, modern philosophers do not spend much time saying they are working in such a tradition, or validating their reflections explicitly in these terms. But the same points that were made in Part IV of the Article apply here as well. To be a part of this practice or this tradition is not to go around saying that you are a part of it, or to congratulate yourself on that fact. It is to engage in it, to

45. Burke, Reflections on the Revolution in France, in "NONSENSE UPON STILTS", supra note 27 , at $115-16$.

46. See the account of the drafting of the Declaration of the Rights of Man and the Citizen in L. GotTSChalK \& M. MAdDOX, LAFAyETTE IN THE FRENCH Revolution 8 (1969). See also "NONSENSE UPON STILTS", supra note 27, at 22-25 (discussing the drafting of the Declaration of tle Rights of Man and the Citizen).

47. K. MARX, The Eighteenth Brumaire of Louis Bonaparte, in KARL MARX: SELECTED Writings 300, 301 (D. McLellan ed. 1977).

48. See generally H. ARENDT, ON REVOLution (1963) (esp. chapters 3-6 regarding the philosophical foundations of revolution and the revolutionary tradition). 
actually do the thinking and the conversing with others, and to take that as seriously as it is possible to take it.

\section{CONCLUSION}

I hope the strategy of this paper has become reasonably clear. Modern commumitarians criticize their hiberal opponents for taking what they think of as an external or transcendent point of view on social mores. They criticize them for daring to expose the constitutive norms of our particular community to the harsh glare of abstract liberal reason. They invite us to abandon the liberal stance, to step back inside the warmth and solidarity of the traditions and practices that make our commumity what it is, and to embrace them as a particular way of life to be lived rather than as an object to be rationally evaluated.

My argument is that if we do this, we should do it properly. If there are norms and practices that constitute "our" way of life, then we should embrace them wholeheartedly, and not im a way that leaves it open for us to peek out occasionally and say, "Every commumity needs boundaries," and "I am following the practices of my community," and so on. It is not and has not been the nature of our moral practices to go around saying that sort of thing about them. On the contrary, to congratulate oneself on following "the norms of nty community" is already to take a point of view external to those norms, rather than to subscribe to the comnitments they embody.

Secondly, I have argued that if we are to keep faith with our identity, we should immerse ourselves in our traditions as they are, not as we would nostalgically wish them to be. For us, as for the members of most modern societies, these are traditions of change, diversity, controversy, and reflection. They are traditions of philosophy as well as virtue, practices of thought as well as conduct, comnunities of reflection as well as moral sohdarity.

No practice or tradition is self-validating, of course, and it may be that by doing all this we are nraking an appalling mistake. There may be reasons for thinking that we would do better to abandon our heritage of liberal critical reflection. Philosophical arguments are sometimes produced to that effect. ${ }^{49}$ But they cannot be conimunitarian arguments: noone can deny that it is part of the particular heritage of our community to think critically and abstractly on nioral nuatters. If we want to engage in the practices of our community, we do better to get on with that thinking and to take it seriously, than to yearn vainly and fatuously for a tradition and a nioral ingenuousness that we never really shared.

49. See, e.g., R. Rorty, Philosophy aNd the Mirror of Nature (1979). 
